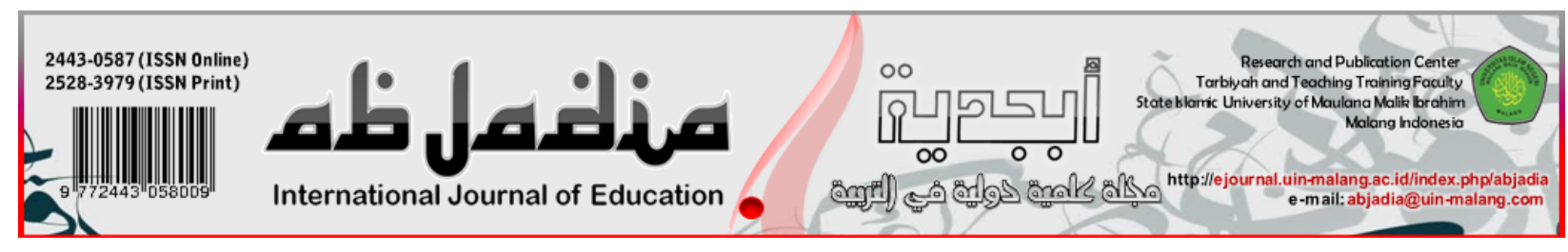

\title{
STUDENTS' PERCEPTION ON THE USE OF ESTAFET WRITING GAME AND PICTURE BASED-CREATIVE WRITING TO NURTURE LOVE OF WRITING
}

\author{
Erna Iftanti \\ Institut Agama Islam Negeri (IAIN) Tulungagung, Indonesia
}

\begin{abstract}
Article History:
Received : 2019-02-07

Revised : 2019-02-19

Accepted : 2019-03-04

Published : 2019-06-30
\end{abstract}

\section{Keywords:}

Estafet Writing Game, Picture Based

Creative Writing, Love of Writing

Correspondence Address:

ernataufic72@gmail.com

\begin{abstract}
To create a quality education, mainly on EFL instruction, the EFL teachers need to be empowered with improving their teaching quality. The students, on the other hand, should also be actively engaged during the instructional activities. Due to the fact that love of "writing" as one of the language skills is not yet established among the EFL university students, the effort of finding out an innovative way of helping them to establish love of creative writing is a must. One of the ways is collaborative writing through Estafet Writing Game and Picture-Based-Creative Writing strategies. Thus, this article aims at describing the students' voices on the use of those strategies to establish love of creative writing. The study conducted through a reflective questionnaire survey to $165 \mathrm{EFL}$ university students reveals that most of the respondents prefer Estafet Writing Game to Picture-Based Creative Writing in terms of its effectiveness to build their creativity and spontaneity of writing skills. To sum up, these strategies are pedagogically meaningful to improve the EFL students' creative writing, because they can collaborate with their peers and promote their cooperative communication. Therefore, it is useful to establish love of writing and to stimulate their ideas for writing.
\end{abstract}

\section{C) Introduction}

There are many studies concerning with writing for EFL students. Yet, it is hardly found a study on building love of writing. Kiriakos \& Tienari, 2018 prove that advocating the perspective of love can encourage discussion on academic writing so that it reflects the multifaceted experiences of writers and unleash its potential in confusing and disrupting. Moreover, love offers a language to talk about vulnerability and courage and viewing writing in the light of love can help students to learn more about themselves and their activities as writers. Besides, McDonough et.al (2018) who conducted study on the quality of collaborative writing, collaborative prewriting, and individual texts in Thailand- in which English is considered as foreign language as that in Indonesia- found "the collaborative texts were more accurate than the collaborative prewriting and no collaboration texts, while the collaborative prewriting and no collaboration texts contained more subordination." Therefore they suggest the future researchers to investigate the role of collaboration at various stages in the L2 writing process. In 
response to this research, it is essential to carry out a study collaborative based writing instruction.

Still, it is often claimed that writing is not an easy subject to learn. The fact revealed from observation to students taking Writing Course at tertiery level indicates that the students who are learning to write get much problems in starting what to write and how to write. A study of Phuket \& Othman (2015) also proves that writing is the most difficult language skill for EFL students, therefore they investigate the sources of error they usually made. Various problems concerning with EFL writing such as lack of linguistic knowledge, word-for-word translation, cohesion errors, and lack of academic style have also arised (Hammad, 2016), writing awareness (Thuy, 2016), lexical and content aspects of writing (Al Seyabi \& Tuzlukova, 2014), punctuation and capitalization, grammatical structure, and language use (Nazim, 2018).

Some other problems concerning students' English essay writing problems included lack of linguistic knowledge, word-for-word translation, cohesion errors, and lack of academic style. This portrait of writing problem ignites the reseacher to build love of writing as the grounded solution of the problrm. To love writing is an indicator of having positive attitude towards writing and it is the influential factor of the EFL students' success of writing. Altınmakas \& Bayyurt (2018) in their study found that one of the factors influencing undergraduates' writing is their perception about academic writing and disciplinary text genres. Similarly, Setyowati \& Sukmawan (2016) in their study reveals that students who have high attitude towards writing view writing as interesting and challenging. Hence, to reach the ability to write needs to built their love towards writing. The term love of writing in this study is defined as releasing the students from having difficulties to start writing. It is believed that if they do not get any difficulties anymore, they will feel free, relax, and finally they can build love of writing.

One of the interesting ways to teach writing is by collaborative strategy of writing with which the students are collaboratively work with their peers to produce a piece of writing. Collaborative works help EFL learners to be more engaged in interaction with greater mutuality when the lower-proficiency learners have the task role as information holder (Dao \& McDonough,2017) so that the relax classroom situation can be built. Thus, the main goal is to create an amusing classroom atmosphere so that they would not anymore feel being trapped in difficulties during the process of writing. Collaborative writing is also proved to help students to improve their personal writing, (Bikowski \& Vithanage, 2016). Moreover, McDonough et.al.(2018) who studied on the quality of collaborative writing compared with individual texts in Thai EFL contexts also reveals that the collaborative texts are more accurate than non-collaborative texts. This article is then intended to portray the EFL university students' voices on implementing Estafet Writing Game and Picture Based-Creative Writing as parts of collaborative strategy.

\section{[Q] Method}


Since this study was intended to dig up the social phenomenon on the EFL students' views on the implementation of Estafet Writing Game (EWG) and PictureBased-Creative Writing (PBCW) strategies to shape love of creative writing, then descriptive study was employed. The subjects of this study are the EFL students attending Creative Writing Class in State Islamic Institute of Tulungagung. Both fun strategies of teaching creative writing are implemented in a certain procedures. The Estafet Writing Game done to help students building an in prompt creating writing was implemented in four steps, namely preparation, action, reading performance, and peer feedback.

\section{Preparation Step}

1. First of all, the class consisting of 40 students is divided into two big groups.

2. The members of each group sit in their own circle.

3. Each member puts number tag on their chests. They prepare paper(s) and each member should bring a pen.

4. Then, the class will decide the theme of the story they will develop in a certain type of creative writing they all agreed with (short-short story).

5. The lecturer determines the length of time each group should finish their creative writing, i.e 25 minutes.

\section{Action Step}

After all the preparation are ready, each member focus on how to develop the theme into

\section{Story}

1. The lecturer announces that the game starts

2. Student with the number tag 1 should start writing a sentence

3. The next students with the following number tags should continue writing, so that each group can produce a piece of a story.

\section{Reading Performance}

1. The writing product of each group is then read in front of the class by the representative of another group.

2. The lecturer will announce the winner of the group. The criteria of the winner are any group who can completely finish the story in the determined time.

3. The story should consist of exposition, raising action, climax, anti climax, falling action, and resolution.

\section{Peer Feedback}

1. The group will exchange the writing

2. They keep sitting in a circle 
3. They will divide themselves into three feedback groups, i.e. "grammar group", "content group", and "organization group".

4. Each member of the group gives feedback in turns.

5. They will return the work and revise their writing product in accordance to thegiven feedback.

This game is done 4 times within four meeting with the number of group member is getting smaller in the following meetings. In each meeting, the students produce different type of creative writing, namely poem, diary, and fairy tale. To know the students progress in their creative writing, they are assigned to write their own piece of creative writing. The formation of group member is assigned by the students themselves in order to set group dynamics so that the writing process and outcome will be more successful (Hassaskhah \& Mozaffari, 2015).

Like EWG, Picture Based Writing Game is conducted through 4 steps as well. However, in this fun strategy, the students are assisted with pictures hang on the wall.

\section{Preparation Step}

1. First of all, 4 pictures are stuck on each corner of the wall

2. The class which consists of 40 students is divided into 4 big groups (10 members for each group).

3. The representative of the group takes the lottery to decide which picture they will write on within 30 minutes.

4. They have at glance discussion on what and how to write.

5. They start writing based on the result of the group discussion

6. They prepare paper(s) and each member should bring a pen.

7. Then, the class will decide the theme of the story they will develop in a certain type of creative writing they all agreed with (short-short story).

8. The lecturer determines the length of time each group should finish their creative writing, i.e 25 minutes.

\section{Action Step}

After all the preparation are ready, each member focus on how to develop the theme into one type of creative writing.

1. When the lecturer counts to start writing, all members of each group run toward their own selected pictures to take a look and find idea to write.

2. Then they, in return each other, are developing their idea into a story in their group.

\section{Reading Performance}

1. The writing product of one group is then read in front of the class by the representative of another group. 
2. The lecturer will announce the winner of the group. The criteria of the winner are any group who can completely finish the story in the determined time with the more complete plot.

3. The story should consist of exposition, raising action, climax, anti climax, falling action, and resolution.

\section{Peer Feedback}

1. The group will exchange the writing

2. They keep sitting in a circle

3. They will divide themselves into three feedback groups, i.e. "grammar group", "content group", and "organization group".

4. Each member of the group gives feedback in turns.

5. They will return the work and revise their writing product in accordance to the given feedback.

To get the data about the students' perception on the implementation of those two strategies of teaching writing, written responsive interview was administered to the subject of the study at the end of the course. The collected data which are in the form of qualitative ones were subsequently analyzed qualitatively by considering the related theories on collaborative writing.

\section{Result}

After one semester implementing these two methods, Estafet Writing Game and Picture-Based Creative Writing, it can be reveaved that these games are believed to be fun and exciting. Both bring about having some positive perception in terms of creativity and spontaniety for shaping the students' creative writng. The findings of this study indicate that the EFL students joining Creative Writing Class claim themselves to be interested in implementing either Estafet Writing Game strategy or Picture-Based Creative Writing for some reasons.

\section{Estafet Writing Game}

First, concerning with the writing creativity, this strategy triggers students to get rilex, fun, and happy, so that they can create idea. It is because, students are told to write everything they think about the approved topic in an exciting situation in which the students working in group are positioned in a competitive atmosphere.

"I am very interested and happy with these games. Of course, because indirectly, the lecturers train the creativity of the students through these games. If this game is applied with more leverage, then these games will greatly assist students in fostering greater creativity of them" (Risyia)

Han \& Hyland (2015) who explore learner engagement with written corrective feedback in a Chinese tertiary EFL classroom found the complexity of learners' 
engagement within and across the cognitive, behavioral, and affective dimension. This indicates that working in group with peers is influential for the EFL students' writing as in line with this result of this study. Working in group with their peer creates the students engagement in a rilex and joyful atmosphere. Moreover, the use of cooperative learning can improve the students writing skill (Astuti, 2016).

Another significant point to be noticed is that EWG strategy is proved to have some exciting activities encourage the students to work fast to create a story by continuing their group peers' writing in a limited time. They feel to be a competitor of the other group, so that they are encouraged to win the game by producing a story in their own word estafetly with group member. Each member has to write one sentence connecting the previous sentences made by their previous group mates. They are forced with the learning situation construct sentences which further build a story. This learning atmosphere is believed to successfully build the students' writing creativity. This fact is clearly seen in the following student's statement:

I am interested in Estafet-Writing Game and Pictured-based-Creative Writing, because this is very exiting activity and a creative writing game skill, that I can ever had. I think this game run so fast, to appropiate our writing topic from our friends. Even though the time is very limited, we must decided to get a story based from our friends written. (Nuri)

Third, in relation with spontaneity, this study proved that the implementation of EWG which focuses on encouraging the students to write and write without giving much concern on grammatical matters mainly in the drafting phase is meaningful to build students' creative writing. They are demanded and challenged to write as many sentences as possible. This is done to attract them to arouse ideas and developing those ideas into writing. As explicitly stated in the following quoted statement:

Yes, it is effective to build spontaneity in writing. Actually this game teach the students how to make a story with ignored grammatical rules, and others...This game also trains the students speed writing, write many sentences as much as they can and actually it can make spontaneity on their creatively writing. (Anggi).

\section{Picture Based Creative Writing}

Meanwhile, for Picture-Based-Creative-Writing, students are asked to arrange a piece of creative writing spontaneously based on the images hang on the wall. The study proves that the strategy satisfying the students to train their creativity in writing. This is due to the fact that each student either the work in group, in pairs, or individually is demanded to create a piece of writing accordingly. It is because they are more challenging to creatively and the picture is taken as media telling rich and resourceful idea to write. Commonly, the students get confused to start writing because they do not have any idea and to develop the plot. Hence, pictures are considered helpful media to attract the 
students' creativity in digging up their own idea of writing and developing the idea into one type of creative writings, such as short story, narrative essay, a poem, a legend, fairy tale, and so on. As explicitly stated in the student's comment below:

\begin{abstract}
"I prefer choose Pictured-Based-Creative Writing...make the student more creative, because when they look the picture before start the writing, it makes the student has more creative ideas to make creative writing. It is very effective to build my creative writing skills, why, because by using this method, I can imagine many things after looking for the picture.(Fandi)
\end{abstract}

In addition, the selection of this learning model- integrating working in group and the use of picture as media- is important to elicit the students' enthusiasm while following the instruction. As revealed by Ningsih \& Razak, 2017 who use text as media of arousing the idea of creative writing that the application of Cooperative Integrated Reading and Composition model is helpful for students to pour the idea that the text is not only read in their own circles but it can also be published.

Besides, PBCW is believed to be useful to build the students' creativity in their Creative Writing Course" because they do not have any idea except after taking a look at the picture. They are then chalenged to write in accordance to the depth observation of the picture. As being claimed by one of the respondents:"The creativity of the students will increase by using this game. Because the students didn't see yet the picture before and they have to write down it based on the picture directly. However the activities included in this strategy are felt to exciting.

I am interested in.... pictured-based-creative writing, because this is very exiting activity and a creative writing game skill, that I can ever have. The creativity of the students will increase by using this game, because the students didn't saw yet the picture before and they have to write down it based on the picture directly. (Anggi)

Moreover, the rules of implementing PBCW is believed to be helpul for students to get writing inspiration, as reflected in one of the student's comments: "Yes, I think those games could help me to build my spontaniety in writing. When the time is running, it is automatically forced me to think hard and getting the inspiration. With the supported theme and pictures, I can imagine something properly. The PBCW has made them to be more inspirable to find what they should write through the picture than think based on a given topic. The pictures or images are valuable to attract their imagination about the pictures and correlate the information and ideas from the picture with the real lives to build new ideas for their writing. This is parallel with a study by Gutiérrez at.al (2015) advocating that the intervention of Picture series technique can improve the overall growth of writing skills, specific to the areas of Transition or logical sequence and Ideas exposure.

Yet, one thing that needs to be significantly noticed is that the lecturer should play his significant role to give brief instruction and give a model to creatively write to their students. As explicitly stated in one of the respondent' statement: “...In addition, 
lecturers also play an important role in this game by giving direction briefing to their students. So, I am very interested and happy with these games. (Nurillah). The positive voices of the students towards their loves of writing has been proved through this study. This is because the lecturers has trained the students' creative writings in an interesting learning atmosphere, so that their love of writing can be gradually set. As stated in the respondent's quotation that she wants this strategy be more influential: “...If this game is applied with more leverage, then these games will greatly assist students in fostering greater creativity of them." (Ais). She further claims that this strategy is also helpful to nurture spontaneity of writing creatively, because the picture provided for her can stimulate her brain and mind to recall words and create ideas useful for starting to write. "Pictured-Based-Creative Writing is very effective to build my spontaneity of creative writing. This method stimulates my brain and my mind spontaneously to remember many words and many ideas to start my writing."(Ais). Like a study by Nazim (2018) indicates that the students' writing skill improves not only because of the professional teacher who taught them and the students.' engagement in writing activities but also put them in the joy of practicing.

\section{¡iini Discussion}

The result of this study has yielded significant point that in order to help EFL students to set love of writing is by inviting them to get involved and engaged in their own creative writing. Writing, mainly on creative writing, as skill is not sufficient only to be taught, still, it needs to be nurtured through an innovative way with which they feel joy to do their own creative writing. Collaborative strategies namely Estafet Writing Game (EWG) and Picture Based Creative Writing (PBCW) are proved to be meaningful to create a joyful competitive activities among themselves and further triggers their creativity and spontaniety in writing. Therefore, they feel rilexed and will not be trapped in their own writing problems. This is because they collaborate with their peers in a group to create and produce a piece of writing. Peer feedback as part of writing process is also helful to measures mainly on their writing accuracy in grammar. This atmosphere, subsequently, brings students about not only solving their confusion and constraint to start and develop writing but also to build love of writing. The result of this study can be pedagogically implemented to Creative Writing for the seek of helping the EFL students arousing their creativity and love of writing. Still, it suggested for the future researcher to verify it by conducting an experimenting study.

\section{哭 Conclusion}

Based on the results of the study it can be concluded that the ability to forgive others in MTs students increases after the application of value clarification techniques or value clarification techniques is effective in increasing the ability to forgive others in MTs students. 
Suggestions for research are: (1) To get maximum results in the application of value clarification techniques, the counselor is expected to pay more attention to the cultural factors possessed by the subject, in the context of this research the counselor is expected to be more active and open. This condition needs to be created so that the counselor can act as a model for students / students in order to develop a more open and active attitude, not only in training activities such as those carried out in this study, but more towards students' self-development goals to meet the future. (2) Further researchers are expected to further deepen the research topic. If in this study forgiveness is seen from an interpersonal perspective, it is expected that the next researcher can conduct research on self forgiveness (self-forgiveness / intrapersonal forgiveness), which is also a matter that needs attention, in order to maximize character education activities.

\section{Bibliography}

Al Seyabi, F., \& Tuzlukova, V. (2014). Writing problems and strategies: An investigative study in the Omani school and university context. Asian Journal of Social Sciences \& Humanities, $3(4), 37-48$.

Altınmakas, D., \& Bayyurt, Y. (2018). An exploratory study on factors influencing undergraduate students' academic writing practices in Turkey. Journal of English for Academic Purposes.

Astuti, E. W. (2016). The Use Of Cooperative Learning To Improve Students'writing Skill On Procedure Text.(A Classroom Action Research At the Eight Grade of SMP Muhammadiyah 6 Plupuh, Sragen in the 2015/2016 Academic Year). Karya Ilmiah Mahasiswa Progdi Pendidikan Bahasa Inggris FKIP, 2(1).

Bikowski, D., \& Vithanage, R. (2016). Effects of web-based collaborative writing on individual L2 writing development.

Dao, P., \& McDonough, K. (2017). The effect of task role on Vietnamese EFL learners' collaboration in mixed proficiency dyads. System, 65, 15-24.

Gutiérrez, K. G. C., Puello, M. N., \& Galvis, L. A. P. (2015). Using pictures series technique to enhance narrative writing among ninth grade students at Institución Educativa Simón Araujo. English Language Teaching, 8(5), 45.

Han, Y., \& Hyland, F. (2015). Exploring learner engagement with written corrective feedback in a Chinese tertiary EFL classroom. Journal of Second Language Writing, 30, 31-44.

Hassaskhah, J., \& Mozaffari, H. (2015). The impact of group formation method (student-selected vs. teacher-assigned) on group dynamics and group outcome in EFL creative writing.Journal of Language Teaching and Research, 6(1), 147-156.

Hammad, E. A. (2016). Palestinian University students' problems with EFL essay writing in an instructional setting. InTeaching EFL Writing in the 21st Century Arab World (pp. 99-124). Palgrave Macmillan, London.

Kiriakos, C. M., \& Tienari, J. (2018). Academic writing as love.Management Learning, 1350507617753560 . 
McDonough, K., De Vleeschauwer, J., \& Crawford, W. (2018). Comparing the quality of collaborative writing, collaborative prewriting, and individual texts in a Thai EFL context. System,74, 109-120.

Nazim, M. (2018). Writing As A Skill: Problems Identified And Pedagogical Remedies. Advances in Social Sciences Research Journal, 5(7).

Ningsih, W., \& Razak, N. K. (2017). The Effectiveness of Cooperative Integrated Reading and Composition Model in the Teaching and Learning Narrative Essay Writing. Journal of Indonesian Language Education and Literary, 2(2, Dec.), 134-137

Setyowati, L., \& Sukmawan, S. (2016). EFL Indonesian Students' Attitude toward Writing in English.

Phuket, P. R. N., \& Othman, N. B. (2015). Understanding EFL Students' Errors in Writing. Journal of Education and Practice,6(32), 99-106.

Thuy, N. H. H. (2016). Teaching efl writing in Vietnam: Problems and solutions-a discussion from the outlook of applied linguistics. VNU Journal of Science: Foreign Studies,25(1).

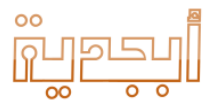

